\title{
Contemporary Food
}

\section{$1 \quad$ Lifestyles}

The weight of tradition is clear in modern Central Asian foodways. They are, on the whole, much as the Medieval travelers described them. By far the most obvious change is the coming of New World food crops: maize, potatoes, tomatoes, green beans, and others. These were totally new when they appeared in the 15 oos and spread only slowly; they received a major boost from the UssR. They are still spreading today. Influences from China and India have become stronger but were evident from earliest times.

The Eurasian heartland reminds us more clearly than any other region on earth that humans cannot eat grass or wood, as many animals can, and that most of the earth's land surface is covered with grass and wood. As we have seen, only a tiny percentage of the area has soil and water adequate for crops. The rest is covered with vegetation that provides food for humans only when cycled through herbivorous animals.

This is a fact that vegetarians conveniently ignore. Vegetarians survived and even thrived in the least desertic parts of Central Asia- the Buddhist monks, nuns, and priests, most notably_-but they still depended on dairy products. Few if any vegans could survive. Although farming has been important in the region for over 7,00o years, hunting and stock-raising have always been the only food-productive uses of most of the land. Recently, as overhunting has caused game to diminish, stock-raising has become even more important.

Nowadays, the limited farmland produces largely grain and fiber (cotton), as well as fruit and a few vegetables; most of the latter are now New World ones. They are better adapted to the extreme conditions than most Old World vegetables.

Earlier influences in the region had been overwhelmingly from the Near East via Iran and the steppes, but increasing influence from Russia in the 19th century led to substantial takeover of all the region by Russian brands, except for Xinjiang and Inner Mongolia. Processed food such as canned items, jams, snacks and cookies tend to be Russian, or, failing that, from Eastern European countries formerly in the Soviet orbit. Borscht and many excellent forms of Russian salad are ubiquitous on menus. Bread and trimmings are Russian style, to the comfort of the traveler, since even poor imitations of Russian bread are generally superior to the white tastelessness of mass-produced international 
breads. Meals in hotels and resorts follow Russian presentation norms. Vodka is common, even for breakfast in Mongolia. Islam mercifully saves most of the region (notably, not Mongolia) from the heavy alcohol abuse so chronic in Russia and Eastern Europe. Even so, abuse is far from unknown.

In an earlier age, influences went the other way: Russia got tea, shashlik (kababs), filled dumplings, noodles (or at least some noodle dishes), and much else from the Eurasian heartland, or from Iran via the Caucasus. Pickles, caviar, and a general fondness for herbs and vegetables came, in large part, from Iran via the same route.

Chinese influences are increasingly strong in Xinjiang and Inner Mongolia, where the majority of the population is now Han Chinese, and the indigenous peoples suffer increasing discrimination. Inner Mongolian food has long had Chinese influences, and the Gansu corridor has always blended Chinese and Inner Asian foodways. In Medieval times, Central Eurasian influences on Chinese food were strong, ranging from breads and dumplings to the whole range of dairy products. All this influence was much stronger in the North, but the South did not escape. Borrowing almost stopped after the Mongol period. The breads and dumplings stayed, but milk products disappeared. Françoise Sabban, the leading expert on this and many other aspects of Chinese food history, calls this "a forgotten savoir-faire."

In contrast to China, the Near East has contributed much to the cuisine of the Eurasian heartland. This is for three reasons: first, agriculture was first in the Near East, and it naturally contributed to all the realms around it; second, the Eurasian heartland, in early historic times, was populated largely from the Near East and Eastern Europe; third, and most important, Central Asia is climatically and ecologically like the northeastern Near East and very unlike China or India.

This being so, it is no surprise that the staples are still the familiar Neolithic ones: the grains are wheat and barley; the dominant animals are sheep, goats, and cattle; and that the dominant fruits are grapes, pomegranates, and melons. The Eurasian heartland itself contributed the horse and the apple. The dominant vegetables are cucumbers, onions, garlic, cabbage (the western species, Brassica oleracea), coriander, carrots, and other Westerners. Sesame seeds are commonly sprinkled on breads and other baked foods. Spices are most commonly cumin, coriander (both leaves and ground fruits), and other apiaceous seeds from the Near East, as well as black pepper and cinnamon from India. Cardamom and cloves have become common in the Indian-influenced

1 Anderson, The Food of China; Sabban, "Un savoir-faire oublié: le travail du lait en Chine ancienne," Zibun: Memoirs of the Research Institute for Humanistic Studies 21(1986), 31-65. 
cooking of Afghanistan. Saffron is an expensive spice used in the areas nearest its current center of production and use, Iran. Ginger, when used, is in its dried and ground form, as in India. The Chinese use ginger fresh; this is not done in western Central Asia. Fresh ginger does occur widely in Indian cooking, but Indian uses have not spread far into the Eurasian heartland. Thus, the use of fresh ginger is largely confined to the areas now part of China.

Kababs, stews, and soups with large chunks of ingredients, thick stews, layered dishes, and any and all baked goods indicate Near Eastern origin. Stews of meat and fruit do also; these go back to Greek and Roman ideas, and were helped in their transmission by medicine, since the ancient Greeks recognized that fruit made heavy meat dishes more digestible. They often phrased it as a heating/cooling issue (meat being heating, fruit cooling). There were naturally other theories in play, but the sheer pleasure in the combination remains the dominant explanation. The Persian world has always idealized putting all sorts of fruit, herbs, and light vegetables in meat dishes. Ibn Khaldun in North Africa wrote that he "counted forty kinds of vegetables and meats in a single dish." ${ }^{2}$ This would be derived from a Mesopotamian, probably Persianized recipe. Recipes including "everything but the kitchen sink" were already known in ancient Mesopotamia ${ }^{3}$ and cast a long shadow over Persia and hence Central Asia - with a steady falling off in numbers of fruits and vegetables as one moves from Persianized south and east Afghanistan to Mongolia.

Concentrating on flowers, Central Asia seems not to use rosewater and rose petals on any significant scale, though they are passionately adored in food and as tea in many parts of the Near East and Mediterranean. Desserts are the milk puddings, ground rice puddings, and halvas, just as in the Near East.

\section{Bread}

In terms of culinary style, the most visible, obvious, and important Near Eastern contribution is bread. Most often, it is the Persian form known almost everywhere by the Farsi name nan. Everywhere in the Eurasian heartland along the main routes, the influence of Iran is overwhelmingly obvious in the bread. It is usually the flat, circular, leavened Persian bread, typically sprinkled with sesame seeds. This is known in Farsi as nan and the word has now spread through most of the Eurasian heartland. Often, it is pronounced non-o as in

2 Dale (2015), The Orange Trees of Marrakesh: Ibn Khaldun and the Science of Man, 232.

3 Bottéro (2001), Everyday Life in Ancient Mesopotamia; Bottéro (2004), The Oldest Cuisine in the World: Cooking in Mesopotamia. 
"log." This is a regular sound-shift: eastern Iranic languages usually convert long $a$ to open $o$, so, for instance, Afghanistan is pronounced Aufghaunistaun in that country, and was often so spelled by 19th-century British travelers. The same sound-shift has occurred in Uzbek Turkic.

Persian bread has spread far beyond the word. It reached China probably with Persian refugees from the Muslim conquest in the 8th century; Persian refugees were apparently selling nan on street corners. ${ }^{4}$ In central and eastern China it shrank over time, becoming the shaobing, 燒餅, “roasted cake," of today. Western China has moved in the opposite direction, making very large raised wheat flatbreads covered with sesame seeds (a specialty of Muslim areas). They often contain chopped green onions and are usually eaten with some sort of lamb dish. Buns, rolls, leavened breadstuffs, and unleavened chapati-like breads abound.

European-style industrial loaves are now common, largely because of recent Russian influence. A mild-tasting industrial form of Russian rye is found in stores in the former USSR countries, and in Mongolia, but rye bread is not normally an indigenous Central Asian item. Bread is almost always of wheattoday usually white flour from near-tasteless modern high-yield varieties, which have recently replaced the exquisite-flavored but low-yielding wheats of old. Heritage varieties still exist in remote areas, and should be a first priority for saving and breeding with modern wheats. The old varieties often have disease and weather resistance that makes them valuable today, as well as incomparable flavor.

In many parts of Europe, the Near East, and Central Asia, bread is sacred or highly respected. Rituals involving bread, and often centering on it, abound. ${ }^{5}$ Crumbs are carefully brushed up and disposed of respectfully, sometimes by feeding them to the wild birds. Finnish folklore (from the very edge of Central Asia) tells of a girl who naughtily stepped on a crumb of bread, and it carried her down to Hell (Marja Haikonen, personal communication). A Mountain Tajik from Tajikistan tells of getting into a fist fight over disrespectful treatment of bread, and credits his victory to his having saved a scrap of bread from being stepped on. ${ }^{6}$ The Afghan chef Said Hofiani relates that "Bread is considered sacred, and you shouldn't abuse it or step on it." ${ }^{7}$

4 Schafer, Golden Peaches of Samarqand, p. 29.

5 Van Oudenhouven and Haider (2015), With Our Own Hand, 97.

6 Van Oudenhoven and Haider, With Our Own Hands, 97.

7 Said Hofiani, Afghanistan Cuisine (author, 2008), 147. 
A fascinating footnote to bread studies concerns Cyril Robinson's tireless inquiries into the history of the bagel. ${ }^{8}$ Robinson first noted ringbreads, similar to bagels, found among the Uighurs in Xinjiang. There are ringbreads scattered throughout the Near East and Central Asia. It seems likely that this is one tradition. They are not known to be associated with ancient Israel or Palestine; the Jewish bagel was one of the foods picked up in Eastern Europe, like its inevitable companions, lox and cream cheese. The circle was ritually important in ancient Eastern Europe, and the ringbread may have begun as a ritual product.

Bread is usually leavened, though the unleavened Indian chapati exists in southern Afghanistan and other areas. Leavening today is usually with ordinary yeast, Saccharomyces cerevisiae, whose native home is grape skins and other fruit and seed coatings. It probably spread to baking from winemaking and beer brewing. Other fermenting agents occur or once occurred in local sourdough cultures, but such are now rare.

Wheat succeeds so well partly because it is so versatile. Its sticky gluten allows for leavened bread, and for an infinite range of dishes that depend on dough holding together even in the thinnest sheets and longest extensions.

Anywhere in the Eurasian heartland, outside of the most isolated areas, the most likely food to find on a table, after bread, will be something made of boiled wheat dough. Noodle soup, with long wheat noodles in a rich broth with bits of mutton is the commonest. Dumplings made of various chopped fillings enclosed in a thin wheat-dough skin are also universal. Of the 95 "exotic" recipes in the Yinshan Zhengyao, 23 are noodle-based. Noodle recipes also frequently featured in the Jujia biyong shilei, including this recipes for salma which is often mentioned in other sources as well:

Noodle dish from the Jujia biyong shilei $(22 B, 13)$

\section{Salma ["water polished"] Noodles}

Use the best quality flour. During the spring, the summer, and the autumn use freshly drawn water. Add oil and salt. First mix together uniformly. When the flour becomes dough-like, gradually add water. Press together into balls. Use the hands to [press] open. Make into [flat] lumps. Then sprinkle with oil and water. Combine by kneading one or two

8 Robinson, "The Bagel and Its Origins-Mythical, Hypothetical and Undiscovered," Peteits Propos Culinaires 58 (1998), 42-46. 
hundred times. After doing this three or four times, the dough will be very soft, like a cake. With the dough placed on a table, use an aop'eng 拗捧 and roll out more than a hundred times. If one does not have an aop'eng, knead a hundred times with the hands. When the dough is ready, it can then be divided to make noodle fingernails [i.e., shaped like fingernails]. Put into recently cooled water. Soak for a couple of hours or so, waiting until the noodles are ready. Then put into the pot. [The noodles] will be ample and fine. Make them as one pleases. During the winter months soak the noodles in warm water.

Noodles provide one of the more complex problems for food historians and have attracted endless attention. The earliest known noodles have been found in a Chinese tomb possibly as much as 4,00o years old. ${ }^{9}$ They were apparently made from millet, though possibly from wheat according to a reexamination. Ge Wei and colleagues point out that one cannot stretch out or roll out millet dough-it has no gluten and will not hold together-but noodles of glutenfree grains are made in China by forcing dough through a sieve into boiling water, not by stretching or rolling. The noodles cook without being manipulated. Noodles and dumplings with wheat skins occur in Inner Asian tombs, in what is now Xinjiang, dating to Han and Tang times. ${ }^{10}$

Noodles did not appear in the Western world until they were invented, apparently independently, by the Greeks. This occurred in the later ancient period, probably around $400 \mathrm{CE} .{ }^{11}$ They were known as itria, a word still used in Mediterranean languages. About the same time, flat dough sheets called laganon were being baked, later fried, and layered with cheese and honey. In Sicily_a Greek realm until the Arabs took it in 800 (parts remained linguistically Greek for hundreds of years after that) - the laganon was boiled, interlayered with cheese, and topped with white sauce; the name evolved into lasagna, apparently during the Arab occupation (800-ca. 1100). Thus was born the first modern pasta dish of the West. Many noodle types and dumplings with noodle-dough skins evolved. The story that Marco Polo introduced pasta from China is, of course, pure fiction. ${ }^{12}$

Chinese noodles, mian 麵, spread from the East. The word mian is a general Chinese word for flour and flour products.

9 Wei, Liu, Chen, and Jin, "Can Noodles Be Made from Millet? An Experimental Investigation of Noodle Manufacture Together with Starch Grain Analyses," Archaeometry 53 (2011), 194-204; Feng (2013), Early China: A Social and Cultural History (Cambridge, 2013), 38.

$10 \quad$ Anderson, "Ancient and Modern Foods from the Tarim Basin," Expedition 52:3 (2010), 5-6.

11 Serventi and Sabban (2002), Pasta: The Story of a Universal Food.

12 See Serventi and Sabban, Pasta, for the full history of pasta in the west. 
The cities and oases of the Eurasian heartland were conquered by noodles and by dumplings wrapped in noodle dough, more thoroughly than by armies. Noodles and dumplings are now a major food everywhere. The dumplings may have started as the samusa or samosa of the Arabs; that word is said to be from Farsi sanbosag (Wikipedia, "samosa"). Boiled dumplings may be even older. The word samusa has now been borrowed from Africa to India, appearing in Central Asia as samsa or somsa. On the other hand, archaeological finds of dumplings in Tang Dynasty tombs in Xinjiang ${ }^{13}$ possibly indicate an actual local origin. To the Eurasian heartland, specifically to Siberian groups, e.g., the Yakut and early Turks (by all evidence-but we cannot be sure), we owe the word manty for dumplings. ${ }^{14}$ One or another variant of this word now stretches from Greece (manti) to Korea (mandu), and China (mantou and mantai). They are generally boiled or steamed, and are filled with chopped meat and onions or similar chopped fillings. Despite this, the Chinese mantou are now unfilled - simply steamed dough buns. Russian and East European words for dumplings-pelmeni, vareniki, pierogi — trace back to other Turkic terms. (The Jewish word kreplach, on the other hand, has a Hebrew root.) It appears that the dumpling found its true fulfillment among the Turkic peoples. Italian ravioli possibly descend from Greek manti, but the distinctive word likely indicates a quite independent origin.

In China, they have evolved into large unfilled steamed buns. The small filled dumplings were originally called mantou 蠻頭, as we know from such sources as the diary of the Japanese traveler Ennin in the Tang dynasty..$^{15}$ These dumplings are now jiaozi 餃子 and are steamed or shallow-fried. ${ }^{16}$ The term "wonton" in English is derived from the soup huntun 餛飩. The Chinese is a graphic description of the thick soup with dumplings floating in it; it literally means "original chaos from which the universe formed."17 Mantou has developed a rather grisly folk etymology: it sounds like "barbarian heads," and supposedly commemorates heads seen floating down the river after a Three Kingdoms battle. However, this legend is referred to in only some of the names used for the dumpling in China. The form of the word in the YSZY, for example, is written like a foreign transcription. Filled fluffy buns (as opposed to small dumplings) are now baozi (etymologically "little wrapped ones"), but from Shanghai north they are often still called mantou (Katy Hui-Wen Hung, Facebook postings, Jan. 4-5, 2020).

13 Anderson, "Ancient and Modern Foods from the Tarim Basin."

14 Buell, "Mongolian Empire and Turkicization: the Evidence of Food and Foodways."

15 Reischauer (1955), Einnin's Diary The Record of a Pilgrimage to China in Search of the Law.

16 Anderson, The Food of China.

17 Anderson, The Food of China; Girardot (1983), Myth and Meaning in Early Taoism. 
The following are some sample recipes. Two are for Manti and one for Peremech meat pies:

1. Cut Flowers Manta (YSZY 1, 47B-48A)

Mutton, sheep's fat, sheep's tail, onions, prepared [dried, then soaked] mandarin orange peel (cut up each finely).

[To] ingredients add, according to recipe, spices, salt and sauce. Make the stuffing. Form the manta. Use scisssors to cut out into various flower shapes. Steam. Use safflower to dye the flowers.

2. Oshkovok Manti, steamed pumpkin dumplings (Charles Perry, personal communication Nu'mankhojaev family)

Manti can be stuffed with meat or vegetables. Winter squash is a favorite filling. Since manti are steamed, rather than boiled, the method of sealing the packets doesn't have to be as sturdy as would be the case for ravioli. If the piece of dough is circular, the cook folds it over the filling and crimps closed about half way from one end to the other, before he turns it around, and crimps from the other end to make a sort of clutch purse shape. With a square piece, the corners are usually folded to meet in the center and crimped together to resemble an Egyptian pyramid. The unusual method described below is traditional in the Ferghana Valley of Uzbekistan which produces an unusual scarab shape:

Filling:

1 winter squash such as butternut, about $2 \frac{1}{2}$ pounds before cleaning out 1 onion, minced

Oil for frying

$3 / 4$ teaspoon salt, or to taste

teaspoon cayenne

$1 / 4$ teaspoon cinnamon

$1 / 4$ teaspoon turmeric

With a large serrated knife, cut the squash in half. Scrape out the seeds with a spoon. Bake the squash halves at 35 o degrees until soft, 45 minutes to an hour. When cool enough to handle, scrape the flesh from the rind with a spoon and mash it.

Fry the onions until golden. Mix with the squash paste and salt, cayenne, cinnamon, and turmeric.

Pasta:

4 cups flour 
2 teaspoons salt

2 eggs

About 4 cups water

1 stick butter, melted

1 pint sour cream

Put the flour in a large mixing bowl, stir in the salt and break the eggs into the bowl. Add the water and form into a kneadable dough, adding more water or flour if needed. Knead firmly until smooth and elastic, about 8 minutes. Cover the paste with plastic wrap at least $1 / 2$ hour to rest.

Cut the ball of paste into 8 equal pieces. Remove one to work on and cover the rest with plastic wrap to keep them from drying out. Roll the first piece in a pasta machine as for fettuccine (next to finest thickness). Cut into 4-inch squares and stuff each with 2 tablespoons of filling.

The Ferghana method:

Fold one corner of paste over the filling, then fold the opposite corner over that. Repeat with the other two opposite corners. Place your index finger vertically alongside the flat edge created by the first fold (do not put it next to one of the edges created by the second sequence of folding or the packet will pull apart). Use the index finger and thumb of your other hand to pull one of the packet's corners around that index finger; hold it there with the middle finger of the first hand. Then pull the next corner over the index finger and firmly pinch the two tabs of paste together. Repeat on the other side and tug the packet to give a neat oval shape.

However you fold them, dip the bottoms of the manti into melted butter as they are finished to keep them from sticking to each other or the steamer, and set on a work surface covered with plastic wrap. Put as many as will conveniently fit into your steamer at one time, probably 3 or 4 , and steam over boiling water until the raw dough aroma is replaced by the smell of squash (about 20 minutes). Set aside while working on the rest of the paste and filling. Manti reheat well in a microwave oven.

Serve 1, 2, or 3 manti per person, with sour cream to taste.

Makes about 24 manti.

3. Peremech, Tatar "window" meat pies (Turanmirza Kamal)

2 cups yogurt

Water 


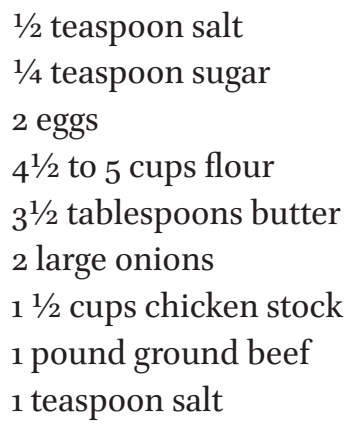

Pepper

1 cup oil for frying

Beat $1 / 2$ cup of the yogurt with $1 / 2$ cup water, salt, sugar, and eggs and add enough flour to make a slightly stiff dough. Knead with the butter until stiff, 7 to 8 minutes. Cover and let rest 1 hour.

Peel and dice 1 onion. Add to the chicken stock in a saucepan and simmer until the onion is soft. Set aside.

Peel the remaining onion, mince, and mix with ground beef, salt, pepper and $1 / 4$ cup water.

Divide the dough into golf ball-sized lumps. You will have about 24 of them. Roll each lump out to circle about $1 / 8$-inch thick. Divide the filling among the dough circles. Place the index finger of one hand in the center of filling and use the thumb, forefinger, and middle finger of other hand to fold the dough up to the index finger. Pinch the dough together in tight pleats.

Heat the oil in a frying pan and fry 3 or 4 peremeche at time, placing them face down ("window side" down) in the oil until golden and then turning over to finish frying. Serve hot.

To serve, spoon some of the onion and broth onto each peremech.Then add 1 tablespoon yogurt.

Makes 8 to 12 servings.

And here, for comparison is an old recipe for samosa (YSZY 1, 29B):

\section{Barley Samsa Noodles}

They supplement the center and increase qi. They strengthen spleen and stomach.

Mutton (leg, bone and cup up), tsaoko cardamoms (five), chickpeas (half a sheng; remove the skins).

Boil ingredients together into a soup. Strain [broth. Set aside meat]. Make [samsa] noodles from a combination of 3 jin of barley flour, 1 jin of 
bean paste. [Fill with] mutton and fry. Adjust flavors with fine qima [finely cut up meat], 2 he of juice of sprouting ginger, coriander leaves, salt, and vinegar.

In Afghanistan, filled dumplings, often containing leeks or Chinese chives as well as meat, are often seen in the dish ashak (Iranic ash, "stew"). This dish involves cooking the dumplings in tomato sauce or something similar and usually includes yogurt. With proper spicing, it is one of the most interesting dishes from the cities and oases of the Eurasian heartland.

In Turkic Central Asia (specifically in Uighur and in other southern Turkic languages), noodles or noodle soup are laghman. This word may derive from Chinese la mian 拉面, pulled noodles, or perhaps the word went in the other direction. We suspect a connection with Iranian lakhsha, seen all over Asia (e.g. Bahasa Malaysia laksa, which has actually been borrowed into Chinese, via Chinese merchants who went to Malaysia and Indonesia and returned home with recipes). There is, for instance, Afghan lakhchak, a lasagna-like dish made with wide flat noodles. Nonetheless, the word laghman is unique to Central Asia and China; Farsi and other languages to the westward lack it. A long discussion of this issue, with countless words from many languages adduced, was aired by Victor Mair and others on "Language Log" in 2014. ${ }^{18}$ There is even a Laghman province in Afghanistan, although its name is a transformation of ancient Lampaka via later historic Lamghan.

\section{Other Grain Foods}

Millet, formerly far more important than now, is normally eaten as porridge. Early accounts show it was often, or even usually, boiled in the stock of boiling meat after the meat was taken out.

Wheat is often made into thick porridge also. Ibn Battuta, commenting on what is now Ukraine or South Russia in the early 14th century, found that the Turks there "do not eat bread nor any solid food, but they prepare a dish made from a thing in their country like millet, which they call $d \bar{u} g \bar{\imath}$." The word now means pounded rice; presumably it was millet at that time. They boiled water, stirred this in, added meat if they had it, and ate it with yogurt or kumiz. He also describes eating it—dūqu this time- - with dried meat on it. ${ }^{19}$ This would be similar to the various wheat-and-meat porridges of the Near East and Cen-

18 Go to < http://languagelog.ldc.upenn.edu/nll >.

19 Ibn Battuta, The Travels, volume 3, 539. 
tral Asia, as seen in the YSZY's initial recipes. They also made beer from this grain and called it $b \bar{u} z a^{20}$ - the Persian or Turkic word that is the origin of the English word "booze." (Boza is an Old Turkic word as well as an early Persian one.) The liberal Hanafi Turks drank it without guilt, since though alcoholic it was not wine (khamr) or strong drink; it was nabidh, originally date wine, held legal by Hanafi because of its mild or nearly absent alcohol content. They also drank mead on the same theory. ${ }^{21}$

Most of the Medieval Turkish grain dishes are still prepared by the Central Asian nomads. Apart from the porridgy beer called boza, they are summarized by Charles Perry in the following categories:

1. Preparations of whole grain: talqan (crushed grain, or a porridge made from it; sometimes flour or toasted flour); qawïrmach/qawïrmaq (fried or toasted grain), yarma (split barley).

2. Soups and soup adjuncts: botqa (porridge or soup with small pasta), töp (thick porridge), köchä (crushed grain cooked with dairy products), bulamï (thin porridge), ovmach (pea-shaped noodles), salma (broad noodles of varying shape; in Kazakhstan, where salma is usually rectangular, more often served with boiled or roasted meat, as we might serve rice, than in soup), kesme or kespe (literally, "cut"; this is the modern name for sliced noodles, replacing the Medieval word tutmaj).

3. Breads and pastries: bawïrsaq (lumps or disks of rich fried dough; when fried in mutton fat, they keep indefinitely and are carried by travelers as provisions for the road), quymaq (thick pancake of leavened dough containing egg), chälpäk (pancake or thin bread fried in deep fat), kömäch (thin bread fried in ashes; the coin-sized Kirgiz version is served in hot milk with butter and thickened yogurt), toqach (usually a bun; used as the general word for bread in Kirgiz), chöräk (fine bread; among nomads, only known to the Turkmens and Kazakhs), yupqa (thinnest flatbread, often served or made in layers), qatlama (fried bread made from dough rolled out thin, greased or sprinkled with dried fruit or fried meat, rolled up tightly and then sliced crosswise, jellyroll-fashion), qatïrma (thin bread fried in a qazan), böräk (a small savory pie; among the nomads, only known to the Kazakhs and Turkmens; among the latter, a sort of ravioli). 
The present-day Kazakhs make belish (literally, pillow), a class of pies with various fillings, but this is doubtless a borrowing from the settled Tatars, who have a vast repertoire of pies of various shapes and compositions. It requires a tandoor or other oven, so it is not nomad food..$^{22}$

\section{Cooking Meat}

The importance of meat in Central Asia finds no better documentation than a variant of Omar Khayyam's famous quatrain translated by Edward Fitzgerald:

A book of verses underneath the bough,

A loaf of bread, a jug of wine, and thou... ${ }^{23}$

The variant (in the Persian) has "a book of verses" replaced by "a leg of mutton."24 That version makes sense before dinner, but after dinner the book of verses may seem more appealing.

As noted above, meat came from sheep, horses, cattle, camels, goats, and game. This list is in approximate order of importance, although some groups, notably the Kazakhs, have long preferred horse meat. Game was formerly exceedingly plentiful in many areas; it has been killed off in the last couple of centuries. As we have seen, the Mongols, at least, preserve highly conservationist rules, ${ }^{25}$ but many others do not.

Across the region, there are several ways to cook meat. Two we have met above: cooking bits of it in soup with noodles; or stuffing it, chopped, into dumplings. Other methods are more robust. One is pilau, pilaf, or plov: rice with meat chunks or other chunked, moist items cooked in or under it. There are countless recipes, some of which will appear below. Occasionally, vegetarian pilafs are seen. The word is apparently Farsi, pilau; this led to pilav and thence pilaf in modern Turkish, to palav in Turkmen, palo in Kyrgyz, palau in Kazakh, polo in Uighur, and plov widely in Uzbekistan and the area near it. There are other pronunciations throughout the world. Pilau was picked up into English from Turkish around 1600, the earliest attestations being in travel

\footnotetext{
22 Perry (1997), "The Horseback Kitchen of Central Asia," 243-248 (p. 246).

23 Khayyam (1900), The Rubáiyát of Omar Khayyam, trans. Edward FitzGerald, 98.

24 Arberry (1959), The Romance of the Ruba'iyat, 117.

25 Humphrey and Onon, Shamans and Elders; Metzo, "Articulating a Baikal Environmental Ethic," Anthropology and Humanism 30 (2005), 39-54; Anderson personal research.
} 
books from 1612 (OED). Apparently "the first detailed description of how to prepare a pilaf properly" comes to us from Avicenna (Ibn Sīnā, ca. 980-1037) ${ }^{26}$

Another robust dish is the kabab (pure Arabic: kabāb), a skewer of small bits of meat, typically alternating with small bits of tail/rump fat of the fat-tailed sheep. Other kababs involve meatballs, vegetables interspersed with meat, and long thin strips of meat. Kababs are rarely the huge ones of American restaurants; most are more like Indonesian saté, about 6 inches long with small items skewered. Shishkabab involves marinating the meat. Russian shashlyk is from Persian via Central Asian Turkic and means more or less the same thing as $k a-$ $b a b$, with some implication of being larger and possibly having vegetable cubes interspersed with the meat. Not all shashlyk is on a skewer, and most types of kabab are not; skewered ones are properly sikh kabab.

There are many recipes for meat stewed with vegetables or fruit. Some of these go back to medieval Arab and Persian recipes. ${ }^{27}$ The Persian word ash for stew is limited in use, and in Afghanistan it has become specialized on one dish (dumplings with leeks, osh). It is far more common in Turkic languages where $a s h$ is a generalized term for a dish that is not exclusively meat, and even what we would consider a pastry in some cases. Arabic qurma is more widespread, in various forms and borrowings, as is the equivalent Mongol and Turkic shulen/shölen. The latter is almost universally a thick soup with additives, even gathered foods. This variant is associated with Nepal, Balpo being an old name for that region. The food is basically Mongolian court food even if some of the spicings are not. Note the use of Turkic words for small coins to indicate sizes; using coins to indicate size is a standard Near Eastern device:

A Shülen from the $Y S Z Y(1,27 \mathrm{~A}-27 \mathrm{~B})$

Bal-po Soup (This is the name of a Western Indian food.)

It supplements the center and brings down $q i$. It extends the diaphragm.

Mutton (leg; bone and cut up), tsaoko [large brown] cardamoms (five), chick peas (half a sheng 升; ${ }^{28}$ pulverize and remove the skins). Chinese radish.

Boil the ingredients together to make a soup. Strain [broth]. [Cut up meat and Chinese radish and put aside]. Add to the soup [the] mutton cut into sashuq [coin]-sized pieces, [the] cooked Chinese radish cut up into sashuq-sized pieces, 1 qian of za'faran [saffron], 2 qian of turmeric, 2

27 Rodinson, Arberry, and Perry (2001), Medieval Arab Cookery.

$28 \quad$ A sheng is today $516.19 \mathrm{ml}$. 
qian of black ["Iranian"] pepper, half a qian of kasni [asafoetida], cordiander leaves. Evenly adjust flavors with a little salt. Eat over cooked aromatic non-glutinous rice. Add a little vinegar.

Much rarer, but extremely valued when it does occur, is the roasting of a whole animal and sharing it among a whole group. A rich leader will do this, often to reward his followers and make them more obligated to him. Followers who were not properly feasted would tend to find a more generous host. Steppe politics being what it was, the generous leader would often be an enemy of the stingy one. The survival chances of a stingy leader would then be very close to nil. ${ }^{29}$

The Central Asians also shared in the great West Asian tradition of lavish hospitality and enjoying life with family and friends. Modern medicine has indeed found a correlation between longevity and time spent relaxing with friends.

The Mongols prefer to boil meat, often in large pieces, because boiling preserves the vital essence of the meat, found in the bone and blood. Boiling also helps provide liquids where other liquids are scarce. The Mongols, and other steppe groups, also pit-barbecued whole animals. The pits were lined with aromatic vegetation-leafy willow boughs in a 14th-century recipe (YSZY; see below):

\section{Willow-Steamed Lamb (YSZY 1, 47A)}

A sheep (one with hair),

[For] ingredient construct a brazier on the ground three chi 尺 [about $1.5 \mathrm{~m}$ ] deep. Surround with stones. Heat the stones until red hot. Use a tabaq [plate] to hold the lamb. On top use willow [branches] to cover and seal with earth. Cook until done].

Readers without a farm background need to know something of the strategies involved in using an animal killed in the field. There was blood everywhere, some of which can be recycled into sausage and other products using blood (although such use is prohibited by Islam). As the animal is cooked, people become merry with the good food and drink by their side (alcohol is also prohibited in Islam). There is a great variety of organs. The Mongols, and evidently all nomads before Islam brought in its restrictive rules, ate and still eat literally every part of the animal: skin, head, feet, lungs - everything. They do not now eat the bones, though they probably once had the custom. These were

29 See, e.g., The Secret History of the Mongols, and Robertson, The Kafirs of the Hindu-Kush. 
certainly involved in broth-making. The custom of bone-eating was found until recently among Plains Native Americans in North America, who pounded up the bones and boiled them down to get the last bits of broth and fat. "Bone grease" was highly prized. Worldwide, bones are split and the marrow sucked out after cooking. Some stalls in the huge Tashkent public market still specialize in marrowbones, sawn open for convenience.

Muscle meat can be salted, packed down in grease (which seals it if no meat is left sticking above the top grease layer), or dried. Drying is common in every dry climate in the world. In the Americas, it was known by the Quechua Indian name charqui. This became "jerky" in English, and led to a rather delightful extension of the verb "to jerk" for preparing same. In South Africa, it is biltong. In any event, in a dry climate, muscle meat can be saved indefinitely once an animal is butchered. The meat is often salted for drying.

This is not true of the internal organs. They are moister, richer in nutrients, and largely impossible to preserve. They must be eaten at once. Hence the worldwide popularity of the type of dish represented in Central Asia by the Azeri djyz-byz and Uzbek kalya pocha. This is a variant of the Iranian kale pache (pronounced kah-leh pacheh), "heads and feet." It is a stew of lamb brains, tongues, and feet. The Iranian word has been borrowed, variously altered, all over Central Asia; it has even reached the Uighur, as khoi padji or similar words. Stews of this kind are made from the more spoilable internal organs. The pache of Iran involves head, stomach, feet, and sometimes tongue and other parts of sheep. The Iranian and Armenian equivalent is khawsh, a stew of cow tripe, lamb tongues, and sheep brains. The Armenian version has pig feet. It is often as a hangover treatment; it is definitely a man's dish, though some women love it. There is also an Afghan variant. There are Mexican counterparts such as menudo ("minor" parts) consisting of cow tripe, and birria ("left over"), lamb stew made of anything from butchering. The latter dish probably has Moorish roots, but could go back much farther, to Paleolithic cuisine! El Salvador's sopa de pata of tripe with a cow's foot is similar. Indeed, most cuisines worldwide have something of this sort. From kale pache to menudo, they generally have a reputation as hangover cures.

Blood, as noted, and stray leftover bits and the less damp internal organs can be made into sausage, which provides a use for the animal's intestines. Often much of the muscle meat goes into these also. In Turkic areas, the horse is particularly favored, because it provides a huge amount of good, sweet meat for sausages, as in the kazy of the Kazakh. Horse meat is high in glycogen, "animal starch," used to bank energy by bonding sugars into a long-chain molecule. This makes it taste sweetish when cooked. It tends to be more tender than mutton and other meats. 
Ibn Battuta observed of the Turkic nobility in South Russia: "Their food consists of boiled horse-meat and mutton," cut up with the bone in the meat. ${ }^{30}$ Apparently even royal banquets consisted of nothing else, except kumiz or mead to drink.

Chicken is now common in towns, cities, and agricultural areas. A favorite preparation is tabaka: split, flattened, and roasted, often brushed with oil or covered with tomato or sour plum sauce. It is sometimes confusingly Englished as "tobacco chicken."

Fish used to be common anywhere near rivers and lakes, but pollution, overfishing, and loss of lakes and waterways - the Aral Sea is only the most extreme case-have devastated the once-vast populations of sturgeon, carp, and other good aquatic foods. Sturgeon, once a major food resource of the region, are now facing extinction because of overharvesting for caviar as well as habitat loss. Still available in rivers of western Central Asia is the sander (or zander, pike-perch, Sander spp.), a superb fish with firm white flesh, extremely popular for kababs and roasting. In the east, excellent salmon, trout, sturgeon, carp, and relatives, as well as less gourmet-approved fish, occur in the northwardand eastward-draining rivers of Mongolia.

The "poor man's meat," legumes, are food of settled people rather than of nomads. Chickpeas abound everywhere in Central Asia, but other legumes do not. New World beans and Indian mung beans appear especially in the southern parts such as southern Afghanistan, and soybeans have now moved into Xinjiang, largely in the last 100 years. Yellow split peas are important in Afghan cooking.

Charles Perry summarizes traditional meat use in the nomadic and once nomadic world as follows (transcribed forms are his renderings): ${ }^{31}$

At one time the nomadic Turks must have had a dish of fried meat called qawïrma, to judge from the presence of the word in India (korma), Iran (ghormeh), and the Levant (qawirma). In the latter two places, the name refers to mutton preserved in fat, a sort of mutton confit. The modern nomads (and their settled Tatar cousins to the north) call a fry-up of meat, usually including various organ meats and offal, qawïrdaq (in Kazakh, kuïrdak), and this word has entered Russian as kavardak, 'confusion, disorder, mess.'

In ancient times, spit-roasted meat was called söklünchü. This is from a root meaning "to snatch or tear off").

$30 \quad$ Ibn Battuta, the Travels, 2,95 .

31 Perry, "The Horseback Kitchen of Central Asia," 244-45. 
Dairy products, which the English once called "whitemeat," are all-important throughout the Eurasian heartland. They are the staples of the nomads, today along with what wheat flour they can get. Nonetheless, most of the inhabitants of the region, especially in the East, lack the gene for lactase, the enzyme that allows digestion of fresh milk in adulthood by breaking down lactose-milk sugar-into galactose and glucose. Most human beings stop producing the enzyme lactase at about the age of six. They cannot break down and digest lactose. Fresh milk then causes bloating, gas, and indigestion, comparable to eating a great deal of beans. A young mammal has no need to produce lactase in adulthood, since it encounters milk only in infancy.

In two parts of the world-Europe and East Africa-people have had to depend heavily on fresh milk over a great deal of history and prehistory. Mutations have arisen that allow production of lactase throughout life. Europeans have one gene for this; East African pastoralists have up to four. The European gene apparently arose early in the history of dairying, about 5000-7000 years ago, give or take a millennium or two. ${ }^{32}$

East of Ukraine and the Caucasus, rather few Asians have these genes; in Mongolia and Xinjiang, very few do. Drinking a glass of milk does not hurt much, but beyond that one glass, indigestion generally follows. Asians thus depend on bacteria, Lactobacillus species and others, to break down the lactose. Milk is converted into yogurt, kumiz, or cheese. Hard cheese manufacture both microbially breaks down lactose and disposes of it in the whey.

Alternatively, people can separate off the protein fraction (as hard curds) and discard the lactose-rich whey. Hard balls, cakes, or powder of dried skimmed milk or yogurt are universal staple foods of nomads- the qurt of the Turkic world, aaruul of Mongolia, and kishk of the Arabs. These are usually made from yogurt, sometimes from unsoured milk. If unsoured milk is simply dried, this merely concentrates the lactose, so (often or usually) the milk is soured and the whey is separated.

Butter-making also gets rid of the whey and lactose, but nomads have little time to churn, and in any case, Central Asians tend to prefer using cream to churning and separating the butter. Butter is important for Buddhist worship, so is produced where Buddhism is practiced. Boiling milk and skimming off the successive skins that appear on the boiling milk, which concentrate the fat, is more common than butter-making in many Central Asian areas. The

32 Curry, “The Milk Revolution," Nature 500 (2013), 20-22 
skimmed-off skins, as well as concentrated cream in general, are widely known by the Turkic word qaymaq.

Finally, to some tastes the best way of getting rid of lactose is to make kumiz, fermented mare's milk. Horse milk is particularly high in sugar, to fuel the foal, which must be able to run away from wolves almost immediately after birth. This sugar is great food for yeasts and Lactobacillus. Other animal milks can be used, including cow's milk, in which case sugar must be added, producing a product generally considered inferior. Human milk is also high in lactose-to fuel brain growth, not for escaping wolves-so it might make good kumiz; knowing the nomad world, we are sure someone has tried it.

The drink is extremely popular with the nomadic groups. (It is now obligatory even for urbanized celebrations. At a Ph.D. thesis defense by a Kyrgyz student at the University of Washington, Seattle, her family had kumiz flown from home for the event, and all those present, including author Anderson, had some.) Even Muslim groups consume it, in spite of the Islamic prohibition of alcoholic drinks. Kumiz can also be distilled, producing a vodka-like drink generally known by some derivative of Arabic 'araq, literally "sweat" or "sweated." This standard Arabic word for distilled alcoholic liquids has now spread from Mongolia to Indonesia and from England ("arrack") to Africa. Milk vodka is not as well-known as it should be, and would sell outside Mongolia if someone can figure out a way to mass produce it commercially. It is at least sold in Mongolian supermarkets, so mass production could start soon.

It is hard to explain why the human gene for lactase production in adulthood did not spread from Europe eastward, given the enormous amount of gene flow in history and the obvious usefulness of the gene. The two explanations are that nomads need to preserve the milk anyway and thus to dry or ferment it, and that most of the gene flow was from East to West. These explanations are not fully adequate, and we are left with a bit of a mystery.

\section{Other Drinks}

Tea is called by the Farsi word chai almost everywhere. Cha 茶 is the North Chinese word for the item. The telltale Iranic ending $-i$ shows who really distributed tea throughout the region. Tea was, of course, known before modern Farsi evolved, nonetheless, the Farsi word seems to have displaced any earlier words. One can easily tell which parts of the world learned of tea via the routes of the Eurasian heartland by following the progress of this word, which is the term for tea from Russia to India. Countries that traded directly with China call it either cha or te. The former is the usual word for tea in most Chinese languages. The latter is the pronunciation of cha in Fujian 福建 province, long a 
center of tea production and trade. Chai demonstrates the enormous importance of the Iranic cultural world in Central Asia. Pronunciation usually remains close to the original, but with expected regional changes: in Kazakh the word has evolved into shäy; in Uzbek, choy.

Iranic peoples along the Silk Road as well as along its associated routes, gated and mediated trade and distribution of China's most famous product. This was even true within westernmost China itself. ${ }^{33}$

Tea shops are samovar in Afghanistan. The name shows a Russian background, with extension of the name from the famed Russian teamaking device. The Farsi term chaykhana, "tea house," is common everywhere and is replacing samovar. ${ }^{34}$ As elsewhere in Asia, ${ }^{35}$ the tea house is the center of socializing, the poor man's office, the home of debate and politics, the leading venue for music and other entertainment, and everyone's Third Place sensu Ray Oldenburg. ${ }^{36}$ Islam forbids alcohol; bars are not there to compete. We not aware of active suppression (as there was sporadically in China, ${ }^{37}$ and as there has so often been of coffee houses in the West), but the tea shop role in fomenting political unrest did not escape authorities.'

Sharbat (Arabic, from the root $s h-r-b$, "drink") is fruit juice or blended-up fruit, now often blended with milk, and sometimes flavored with spices or seeds. See below, under Afghanistan.

Alcohol is forbidden by Islam, though plenty of it enters the Muslim countries. Mongolia makes beer and vodka, inevitably named after Chinggis Khan (as spelled on the bottles). It also imports much vodka from Russia. ${ }^{38}$

We have listed above the standard vegetables. In cooking, onions are universal, cut up into slices or chopped and added to salads, soups, and dumplings. Carrots are widely used in pilafs, especially the qabuli pilau and its relations. Potatoes are ever more widely used, often fried. Russian and Iranian influence has made herbs and salads widespread. Few meals in the ex-USSR nations are

33 There are several other words for tea out there; see Mair and Hoh (2009), the True History of Tea, especially Appendix 3 .

34 Dupree, Afghanistan, 153 .

35 Di (2008), The Teahouse: Small Business, Everyday Culture, and Public Politics in Chengdu, 1900-1950.

36 Ray Oldenburg (1997), The Great Good Place.

37 Wang, The Teahouse.

38 On alcohol in central Asia, see Fragner, et al., Wine Culture in Iran and Beyond. A lot more drinking went on than is generally realized. 
without the ever-present cucumber and tomato salad; normally the two are simply cut up, but often they are at least salted, and sometimes given a dressing. Russian salads with mayonnaise and/or beets are general in hotels and international-style restaurants in the ex-USsR countries and Mongolia. Tomatoes enter widely into soups and stews. Garlic chives and leeks are common in Afghanistan and widely used elsewhere in more southerly parts of the region. Vegetables are considered far beneath meat in worth and prestige. Nonetheless, they enter, in their unobtrusive way, into all meals and almost all "made" dishes.

A vast number of shoots and leaves is used for greens, especially in spring. Purslane, dandelion, dock, clover, thistles, cresses, and other less familiar plants are heavily used. Roots such as cinquefoil, wild lilies, wild onions, and clover contribute, as in the case of Cinggis-qan's childhood. Their vitamin C can be lifesaving after the long, hard winters. All traditional people have knowledge of local plants, but pastoralists must be especially aware of them, because the herders have to know what plants are good for livestock, what are poisonous, and what are medicinal. Herbivores usually know what to avoid, but sometimes they eat dangerous plants. They may overeat favored but not ideally nutritious plants - what American ranchers call "candy plants." Humans have, in the past, learned from livestock what can be eaten and what are the effects of specific plants. ${ }^{39}$ Food thus grades into medicine. The Medieval and later texts discuss medicinal eating at great length. These sources explore both the medicinal values of common foods and the edibility of medicinal plants.

Forest foraging occurs in favored areas. Gathered are mushrooms (perhaps especially in Mongolia which has given China one of its words for mushrooms, möög, Chinese mogu 磨菇), young tender pine cones (boiled), and even pine bark. The Siberian stone pine (Pinus sibirica) produces highly valued pinenuts, largely in northern Mongolia.

In short, vegetable foods are highly important in Central Asia. This is a point rarely made in the literature, focused as it often is on animals.

\section{$9 \quad$ Sweets}

The overwhelming popular choice for sweets is fruit, both fresh and dried. The "Strawberry" song that opens this book conveys the popularity of this fruit,

39 Information from Anderson's research on several continents. Discussion with Rainer Bussman, an expert on montane plants of west and central Asia, is gratefully acknowledged. 
which in late spring appears in unbelievable quantities in the markets of the more agriculturally productive areas. Cherries, mulberries, pomegranates, and other spring fruit appear with them. Pomegranates are relatively storable and bear over a long season, making them a more regular food. Their red jewel-like seeds probably gave their name to garnets, because of the resemblance. These seeds are sprinkled on top of pilafs and other dishes. More common yearround are dried mulberries, apricots, raisins, and sometimes other items. Dozens of stalls in the vast Tashkent market, and countless stalls, roadside stands, local shops, and sidewalk set-up tables everywhere in the region, sell nibbles of dried fruit, nuts, and seeds. People spend a great deal of time nibbling on these conveniet foods. Stuffing dried apricots with nuts and raisins is a more elaborate preparation. Dates, generally a rare luxury (less rare in Afghanistan), are similarly treated. Nuts, mostly walnuts but often also almonds, pistachios, and others, are eaten with dried fruit and are made into various pastes and sauces. Stalls and sidewalk vendors provide nibbles of dried fruits and nuts, as in the Iranian world.

Wild berries and fruits are important where found. Cranberries (Vaccinium spp.) are popular, often under the Russian names of kliukva (or klikva) and brusnika. In addition to jam and eating fresh, they sometimes get into horseradish, a wonderful combination. Sea buckthorn (Hippophae rhamnoides) is one of the few good fruits growing in desert conditions, and thus widely used, sometimes grown in small orchards. A wild apple relative called bayarka in Kazakhstan provides good fruit. Wild roses, currants (Ribes), and other fruits are locally available. Wild apples, almonds, apricots, and other wild forms of domestic fruits persist in mountain areas.

More ambitious are the many types of halwa, ranging from simple sweetened flour dough to milk preparations and sesame, carrot, and other halwas. Baklava-type dishes are widely but not commonly found. Russian jams and preserves are much more in evidence.

Elisabeth Rozin ${ }^{40}$ has pointed out that a cuisine is best defined by its signature spicing. Most of Central Asia uses a classic Near Eastern mix: black pepper, coriander (the ground seeds and the fresh leaf), and cumin. Often cinnamon is added. This is well attested in Medieval texts like the Yinshan Zhengyao. Mint and poppy seeds occur, rarely, in the YSZY, and are locally used still. Black cum- 
in (nigella) is occasional, mostly in areas influenced by Indian or Iranian medicine. Today, the New World chile has made an appearance, but it is far less common than in India or Turkey. It is most evident in south Afghanistan, from Indian influence, and in Xinjiang, from western Chinese usage.

In the southwest, more Persian and Arab spices like saffron, sumac, and dill are used. In parts of Afghanistan near India, turmeric becomes common. Chinese use ginger, large cardamoms, and soy sauces and ferments. These did not spread to the Eurasian heartland till recently, and then only in Inner Mongolia and Xinjiang, and very locally in Mongolia. (The large cardamoms in the genus Amomum, different species from the usual flavoring cardamom, are more widespread as a medicine.) Chinese chives spread to Afghanistan and are very popular there.

Sour foods are widely liked. Lemon juice, vinegar, sour plums, and wild sour plants such as dock are popular, but the overwhelming favorite for souring is Lactobacillus. Pickling vegetable foods and preparing soured dairy products and preserved sausages depend on the many species of this all-important genus of bacteria. It would be impossible to imagine life in Central Asia without it, since it preserves and makes available the dairy foods as well as many vegetable items. Pickling vegetable foods is not likely among nomads-where would they put the jars? - but settled people manage it. Central Asia is ringed by the great pickling cultures of the world: Iran, Armenia, Georgia, East Europe, Korea, China, India ${ }^{41}$. These cultures depend on storing food for the winter by this method; the Lactobacillus produces lactic acid that adds to the salt used in pickling to preserve the food thoroughly, though vitamin $\mathrm{C}$ is lost.

\section{$11 \quad$ Cooking Utensils}

Cooking in Central Asia is done in the usual ways, but the nomadic tradition makes grilling, roasting at a campfire, drying, and boiling in a big kettle or pot much more important than they are in much of the world. Settled agricultural people use pottery vessels. Frying pans are often similar to the Indian kuali or Chinese wok. Shishkababs are cooked on a shish, Turkic for sword or skewer. People eat from bowls, using spoons and knives. Forks are a modern import. Chopsticks occur only Han-influenced parts of Chinese Central Asia.

Bread is usually cooked in an earth oven, tandur or variant words; in some places this is a beehive oven, made of bricks covered and sealed with clay. In either case, fuel is burned to heat the tandur to an extremely high temperature;

$41 \quad$ On pickling, see Katz (2007), The Art of Fermentation. 
the ashes are then taken out; the bread is placed on the oven floor or stuck to the walls. Author Anderson observed a tandur dug into the ground in Bamiyan, Afghanistan, that was as big as a room; very long peelboards were used to stick the bread on and later remove it, baked; the skill of the peelboard-wielders was incredible, and the bread was the among best Anderson has ever tasted. Nomads in remote settings use a griddle with a raise to it, like an inverted shallow wok, called a saj in Turkic; other vessels include "oqlaghu (later oklava), a thin rolling pin (from oq, "arrow"); süzgüch, a colander especially used for straining curds; and tägirmän, a stone for grinding grain. Most Turkish languages use the Iranian word hâwan for mortar. ${ }^{42}$

42 Perry, "The Horseback Kitchen of Central Asia," 247. 